\title{
HUBUNGAN INTENSITAS SUARA DENGAN TEKANAN DARAH PADA PEKERJA PT. TRADHA ASPHALT MIXING PLANT (AMP) KECAMATAN PEJAGOAN KABUPATEN KEBUMEN TAHUN 2015
}

\author{
Fakhri Dzulfiqar ${ }^{1)}$, Zaeni Budiono ${ }^{2)}$ \\ Jurusan Kesehatan Lingkungan, Politeknik Kesehatan Kemenkes Semarang, \\ Jl. Raya Baturaden KM 12 Purwokerto, Indonesia
}

\begin{abstract}
Abstrak
Peraturan Menteri Tenaga Kerja dan Transmigrasi No. PER.13/ MEN/ X/ 2011 tentang Nilai Ambang Batas Faktor Fisika dan Faktor Kimia di Tempat Kerja pada pasal 1 menjelaskan bahwa kebisingan termasuk faktor fisika di tempat kerja yang dapat mengakibatkan penyakit atau gangguan apabila melebihi nilai ambang batas 85 $d B$. Kebisingan yang melebihi nilai ambang batas akan mengakibatkan terjadinya perubahan irama jantung dan tekanan darah. Hasil survei pendahuluan di PT. Tradha AMP bahwa sumber-sumber paparan intensitas suara berasal dari alat-alat atau mesin-mesin produksi yang digunakan oleh perusahaan. Pekerja merasakan pengaruh dari suara mesin seperti; gangguan komunikasi saat bekerja, menurunnya konsentrasi kerja, cepat lelah saat bekerja, stress yang berakibat pada ketidakstabilan emosi. Tujuan penelitian ini mengetahui hubungan intensitas suara dengan tekanan darah pada pekerja PT. Tradha AMP. Metode yang digunakan observasional analitik dengan pendekatan cross sectional. Hasil uji statistik menggunakan Pearson Product Moment diperoleh nilai hitung $r_{x y}=$ 0,222 menunjukkan hubungan intensitas suara dengan tekanan darah sistolik rendah (lemah), dengan nilai $p=$ 0,488 lebih besar dari $\alpha=0,05$, sedangkan uji statistik menggunakan Pearson Product Moment diperoleh nilai hitung $r_{x y}=0,056$ menunjukkan hubungan intensitas suara dengan tekanan darah diastolik sangat rendah (sangat lemah), dengan nilai $p=0,863$ lebih besar dari $\alpha=0,05$. Berdasarkan hasil tersebut disimpulkan tidak ada hubungan intensitas suara dengan tekanan darah pada pekerja PT. Tradha AMP tahun 2015.
\end{abstract}

Kata kunci : Kebisingan, Intensitas Suara, Tekanan Darah, Kesehatan Lingkungan

\begin{abstract}
[Correlation Between Noise Intensity With Workers Blood Pressure On PT. Tradha Asphalt Mixing Plant (AMP) Pejagoan Districts Kebumen Regency Year of 2015]. Regulation stated by Manpower and Transmigration Ministry No. PER.13 / MEN / X / 2011 related Physics and Chemistry Factors Threshold at working place in article 1 explaining that noise included as working physical factors that can lead to disease or disorder if exceeding the threshold value for $85 \mathrm{~dB}$. Noise that exceeds the threshold value will result in a change in heart rhythm and blood pressure. Preliminary survey results in PT. Tradha AMP that the noise exposure coming from the tools or production machines used by the company. Workers feel the influence of the engine sound like; communication disorders, reduced concentration, get tired, stress that causing emotional instability. This research objective was; determine the correlation between noise intensity and blood pressure on workers of PT. Tradha AMP. The research method used was analytic observational with cross sectional approach. Statistical test results obtained using Pearson Product Moment shows $r_{x y}$ value $=0.222$ shows correlation between noise intensity with systolic blood pressure was low (weak), with $p=0.488$ greater than $\alpha=0.05$, while the statistical test using Pearson Product Moment obtained $r_{x y}$ values $=0.056$ shows that the correlation between noise intensity with diastolic blood pressure was very low (very weak), with $p=0.863$ greater than $\alpha=0.05$. Based on these results the conclusion drawn there was no correlation between noise intensity with workers blood pressure on PT. Tradha AMP year of 2015.
\end{abstract}

Keyword : Noise Include, Noise Intensity, Blood Pressure, Enviromental Health

\section{PENDAhUluan}

Keputusan Menteri Kesehatan No. 1405 Tahun 2002 tentang Persayaratan Kesehatan Lingkungan Kerja Perkantoran dan Industri menjelaskan bahwa kebisingan merupakan salah satu parameter persyaratan kesehatan lingkungan kerja perkantoran dan industri yang perlu diperhatikan. Peraturan Menteri Tenaga Kerja No. 13 Tahun 2011 tentang Nilai Ambang Batas (NAB) Faktor Fisika dan Faktor Kimia di Tempat Kerja pada pasal 1 menjelaskan 
bahwa kebisingan termasuk faktor fisika di tempat kerja yang dapat mengakibatkan penyakit atau gangguan apabila melebihi nilai ambang batas.

Kebisingan yang melebihi nilai ambang batas akan meningkatkan kadar hormon stress, seperti epinephrine (adrenalin), nore epinephrine (noreadrenalin) dan kortisol tubuh yang mengakibatkan terjadinya perubahan irama jantung dan tekanan darah. Bising yang terus menerus diterima seseorang akan menimbulkan gangguan proses fisiologis jaringan otot dalam tubuh dan memicu emosi yang tidak stabil. Ketidakstabilan emosi tersebut dapat memacu jantung untuk bekerja lebih keras memompa darah ke seluruh tubuh, dalam waktu yang lama tekanan darah akan naik sehingga menyebabkan hipertensi (Tambunan S., 2005). Hal tersebut termasuk gangguan kardiovaskuler (Sasongko, 2000).

Hartati (Surakarta, 2011) menyatakan bahwa pengukuran tekanan darah tenaga kerja di unit boiler batu bara PT. Indo Acidatama, Tbk., sesudah terpapar kebisingan melebihi standar NAB. Tekanan darah sistolik dari 20 subjek penelitian, 16 subjek penelitian (80\%) mengalami peningkatan. Pengukuran tekanan darah diastolik dari 20 subjek penelitian, 12 subjek penelitian $(60 \%)$ mengalami peningkatan. Penelitian yang dilakukan dalam tesisnya oleh Eny Hastuti (Semarang, 2004) meneliti efek kebisingan pada 60 pekerja di Bandara Ahmad Yani Semarang. Beliau menemukan bahwa kebisingan lebih atau sama dengan 85 dBA sebanyak $26,7 \%$ pekerja mengalami kenaikan tekanan darah sistolik dan $33 \%$ pekerja mengalami kenaikan tekanan darah diastolik.

PT. Tradha AMP pada awalnya bernama PT. Tradha Adi Kencana yang berdiri sejak tahun 2007 merupakan salah satu perusahaan penghasil hotmix (aspal beton) di Kecamatan Pejagoan Kabupaten Kebumen. Proses kegiatan usaha sumber-sumber paparan intensitas suara berasal dari alat-alat atau mesin-mesin produksi yang digunakan oleh perusahaan dalam proses produksi seperti mesin generator, mesin Stone Crusher (pemecah batu), Whell Loader dan Asphalt Mixing Plant (mengolah hotmix) sehingga menimbulkan paparan intensitas suara terhadap pekerja. Hasil survei pendahuluan bahwa pekerja di tempat tersebut merasakan pengaruh dari suara mesin seperti; gangguan komunikasi saat bekerja, menurunnya konsentrasi kerja, cepat lelah saat bekerja, stress yang berakibat pada ketidakstabilan emosi.

Tujuan penelitian ini adalah mengetahui hubungan intensitas suara dengan tekanan darah pada pekerja PT. Tradha AMP Kecamatan Pejagoan Kabupaten Kebumen tahun 2015”.

\section{METODE DAN BAHAN}

Jenis penelitian ini adalah observasional analitik dengan pendekatan cross sectional, yakni melakukan pengukuran terhadap variabel bebas dan variabel terikat kemudian menganalisis data yang terkumpul dengan menggunakan analisis data uji statistik Pearson Product Momentuntuk melihat apakah ada hubungan antara intensitas suara dengan tekanan darah pekerja.

Pengukuran intensitas suara dilakukan pada saat mesin-mesin produksi beroperasi menggunakan alat Sound Level Meter.Pengukuran tekanan darah pekerja dilakukan sebelum dan setelah pekerja bekerja terppar intensitas suara menggunakan alat Sphygmomanometer dan stetoskop.Sampel yang digunakan dalam penelitian ini adalah pekerja harian di PT. Tradha AMP sebanyak 12 orang.

\section{III.HASIL DAN PEMBAHASAN}

PT. Tradha AMP merupakan salah satu perusahaan penghasil hotmix (aspal beton) yang bergerak di bidang usaha Stone Crusher dan Asphalt Mixing Plant (AMP) di Kabupaten Kebumen Jawa Tengah. Alat-alat atau mesin-mesin produksi yang digunakan oleh perusahaan dalam proses produksi seperti mesin generator, mesin Stone Crusher (pemecah batu), Whell Loader dan Asphalt Mixing Plant (mengolah hotmix).

Rentang umur pekerja di PT. Tradha AMP berada antara 26 sampai 56 tahun. Umur responden dalam penelitian ini dikategorikan menjadi 2 yaitu $\leq 40$ tahun dan $>40$ tahun, distribusi umur responden $\leq 40$ tahun sebanyak 7 responden $(58 \%)$ dan umur $>40$ tahun sebanyak 5 responden $(42 \%)$. Pengkategorian tersebut dikarenakan pada umur $\leq 40$ tahun cenderung memiliki tekanan darah normal dan pada umur $>40$ tahun cenderung mengalami peningkatan tekanan darah dari normalnya. Menurut Vitahealth dalam Hartati (2011) tekanan darah akan cenderung tinggi bersama dengan peningkatan usia, umumnya sistolik akan meningkat sejalan dengan peningkatan usia, sedangkan diastolik akan meningkat sampai usia 55 tahun untuk kemudian menurun lagi.

Hasil dari observasi seluruh sampel penelitian sebanyak 12 responden memiliki jenis kelamin yaitu laki-laki. Tekanan darah laki-laki umumnya lebih tinggi daripada perempuan, sehingga laki-laki memiliki resiko lebih besar untuk terkena penyakit hipertensi. Menurut Parsudi dalam Subagiya (2007) pada wanita sebelum menopause 5-10 $\mathrm{mmHg}$ lebih rendah dari pria seumurnya, tetapi setelah menopause tekanan darahnya lebih tinggi.

Kondisi kesehatan seluruh responden yang menjadi sampel penelitian dalam kondisi sehat. Hal ini ditandai dengan tidak ada tenaga kerja yang sedang mengkonsumsi obat-obatan. Menurut Depkes RI dalam Hartati (2011) seseorang yang mengkonsumsi obat-obatan seperti oral dekongestan hidung, obat-obat hidung, obat supresi nafsu makan dapat meningkatkan tekanan darah.

Distribusi responden berdasarkan riwayat penyakit diketahui 1 responden (8\%) memiliki riwayat penyakit hipotensi, 1 responden (8\%) memiliki riwayat penyakit ginjal, dan 10 responden (84\%) tidak memiliki riwayat penyakit hipotensi, 
ginjal maupun hipertensi. Vitahealth (2000) menjelaskan ginjal merupakan organ penting dalam mengendalikan tekanan darah, karena itu berbagai penyakit dan kelainan pada ginjal dapat menyebabkan terjadinya tekanan darah tinggi.

Hasil pengisian kuesioner diketahui bahwa seluruh responden tidak ada yang memiliki riwayat keturunan penyakit hipertensi yang diturunkan dari keluarga seperti orang tua atau saudara kandungnya, hanya terdapat 1 responden yang memiliki orang tua (ayah) dengan riwayat penyakit hipertensi. Lany Gunawan (2001) menjelaskan dari data statistik terbukti bahwa seseorang akan memiliki kemungkinan lebih besar untuk mendapat hipertensi, jika orang tuanya penderita hipertensi.

Diketahui perilaku pekerja mengkonsumsi kafein (kopi)/ minuman penambah stamina dengan kategori sering terdapat 7 responden $(58 \%)$, kategori kadangkadang 2 responden (17\%), dan tidak pernah mengkonsumsi terdapat 3 responden (25\%). Pengkategorian tersebut dikarenakan untuk kategori sering bahwa setiap hari responden mengkonsumsi kafein (kopi)/ minuman penambah stamina, kategori kadang-kadang bahwa tidak setiap hari responden mengkonsumsi kafein (kopi)/ minuman penambah stamina, dan untuk kategori tidak pernah karena setiap hari responden tidak mengkonsumsi kafein (kopi)/ minuman penambah stamina. Undari (2006) menyatakan bahwa minuman berkafein dapat mendorong kerja jantung menjadi lebih cepat. Jantung akan memompa darah lebih cepat ke seluruh tubuh. Jika diminum secara rutin dan kondisi tersebut terus berulang maka akan berakibat hipertensi.

Diketahui perilaku responden yang memiliki kebiasaan merokok yaitu 8 responden $(67 \%)$ dan yang tidak memiliki kebiasaan merokok 4 responden (33\%). Miswar (2004) menjelaskan bahwa rokok menyebabkan kenaikan darah selama 2-10 menit setelah dihisap, karena merangsang saraf untuk mengeluarkan hormon yang bisa menyebabkan pengerutan pembuluh darah sehingga tekanan darah menjadi naik.

Hasil pengisian kuesioner diketahui bahwa seluruh responden tidak ada yang sedang mengkonsumsi obat yang dapat berpengaruh terhadap peningkatan tekanan darah seperti obat-obatan oral dekongestan hidung, obat-obat hidung, obat supresi nafsu makan serta obat-obatan terlarang (narkoba). Hal tersebut dikarenakan pada saat dilakukan penelitian seluruh responden dalam keadaan sehat dan tidak ada yang pecandu narkoba.

Diketahui bahwa masa kerja responden antara pekerja baru dan pekerja lama perbandingannya sama yaitu 6 responden (50\%) pekerja baru dan 6 responden $(50 \%)$ pekerja lama dikarenakan pekerja harian dalam proses produksi selalu ada perekrutan tenaga kerja baru untuk menggantikan tenaga kerja lama.

Hasil pengukuran suhu dan kelembaban diperoleh rata-rata suhu tertinggi yaitu $28,67^{\circ} \mathrm{C}$ pada lokasi
Asphalt Mixing Plant dan suhu terendah pada lokasi perkantoran yaitu $26,33^{\circ} \mathrm{C}$, sedangkan rata-rata kelembaban tertinggi yaitu $66,33 \%$ pada lokasi area perkantoran dan kelembaban terendah yaitu $65,67 \%$ pada lokasi Stone Crusher.Suhu dan kelembaban berhubungan dengan terjadinya tekanan panas pada lingkungan kerja. (Suma'mur, 2009) menyatakan bahwa pada lingkungan kerja panas, tubuh mengatur suhunya dengan penguapan keringat yang dipercepat dengan pelebaran pembuluh darah yang disertai meningkatnya denyut jantung dan tekanan darah, sehingga beban kardiovaskular bertambah. Menurut Keputusan Menteri Kesehatan Republik Indonesia Nomor 1405/ MENKES/ SK/ XI/ 2002 tentang Persyaratan Kesehatan Lingkungan Kerja Perkantoran dan Industri, suhu dan kelembaban di PT. Tradha AMP masih dalam kategori memenuhi syarat.

Hasil pengukuran intensitas suara sebagai berikut : rata-rata intensitas suara pada lokasi 1 (mesin Stone Crusher) 87,93 dB, lokasi 2 (area perkantoran) 77,04 $\mathrm{dB}$, lokasi 3 (mesin AMP) 85,73 dB, lokasi 4 (antara mesin $A M P$ dengan area perkantoran) 76,72 dB, lokasi 5 (antara mesin Stone Crusher dengan AMP) $65,43 \mathrm{~dB}$, lokasi 6 (antara mesin AMP dan Generator) 78,42 dB, dan lokasi 7 (samping mesin generator) 80,11 dB. Rata-rata intensitas suara tertinggi pada titik 1 lokasi mesin Stone Crusher yaitu $87,93 \mathrm{~dB}$, sedangkan rata-rata intensitas suara terendah pada titik 5 lokasi antara mesin Stone Crusher dan AMP yaitu 65,43 dB. Menurut Peraturan Menteri Tenaga Kerja dan Transmigrasi Republik Indonesia Nomor Per. 13/ Men/ 2011 Tentang Nilai Ambang Batas Faktor Fisika dan Faktor Kimia di Tempat Kerja menyebutkan bahwa intensitas suara yang diperbolehkan $85 \mathrm{~dB}$ selama 8 jam kerja per hari, sehingga intensitas suarauntuk lokasi mesin Stone Crusher dan mesin AMP tidak memenuhi syarat karena melebihi nilai ambang batas $85 \mathrm{~dB}$. Penggunaan ear plug atau ear muff bagi tenaga kerja dapat mengurangi paparan bising yang diterima sehingga dapat meminimalkan pengaruh kebisingan yang ditimbulkan, tetapi kenyataan di lapangan pekerja tidak memakai alat pelindung telinga. Hal tersebut dikarenakan pihak pengelola PT. Tradha $A M P$ tidak menyediakan alat pelindung telinga jenis apapun untuk pekerja.

Hasil pengukuran tekanan darah sistolik dan diastolik pekerja sebelum terpapar intensitas suara rata-rata tekanan darah sistolik tertinggi yaitu 128,33 $\mathrm{mmHg}$ dan terendah yaitu $103,33 \mathrm{mmHg}$, sedangkan rata-rata tekanan darah disatolik tertinggi yaitu 81,67 $\mathrm{mmHg}$ dan terendah yaitu $70 \mathrm{mmHg}$. Rata-rata tekanan darah sistolik tertinggi setelah bekerja terpapar intensitas suara $87,93 \mathrm{~dB}$ yaitu 138,33 $\mathrm{mmHg}$ dan terendah yaitu $113,33 \mathrm{mmHg}$ dengan paparan intensitas suara $80,11 \mathrm{~dB}$, sedangkan tekanan darah diastolik tertinggi setelah bekerja terpapar intensitas suara $87,93 \mathrm{~dB}$ yaitu $90 \mathrm{mmHg}$, dan terendah yaitu $76,67 \mathrm{mmHg}$ dengan paparan 
intensitas suara 85,73 dB. Pengukuran tekanan darah pekerja yang dilakukan setelah bekerja terpapar intesitas suara ada yang meningkat dan tetap, diketahui bahwa responden yang berada pada paparan intensitas suara $>85 \mathrm{~dB}, 9$ responden mengalami peningkatan tekanan darah sistolik, 7 responden mengalami peningkatan tekanan darah diastolik, sedangkan 2 responden tekanan diastolik tetap. Responden yang berada pada paparan intensitas suara $\leq 85 \mathrm{~dB}, 3$ responden mengalami peningkatan tekanan darah sistolik, 1 responden mengalami peningkatan darah diastolik dan 2 responden tekanan darah diastolik tetap.

Hasil analisis uji statistik Pearson Product Moment hubungan intensitas suara dengan tekanan darah sistolik diperoleh nilai hitung $\mathrm{r}_{\mathrm{xy}}=0,222$ menunjukkan hubungan intensitas suara dengan tekanan darah sistolik rendah (lemah), dengan nilai $\mathrm{p}$ $=0,488$ lebih besar dari $\alpha=0,05$ maka Ho diterima yang berarti tidak ada hubungan antara intensitas suara dengan tekanan darah sistolik pada pekerja. Hasil analisis uji statistik hubungan intensitas suara dengan tekan darah diastolik diperoleh nilai hitung $\mathrm{r}_{\mathrm{xy}}$ $=0,056$ menunjukkan hubungan intensitas suara dengan tekanan darah diastolik sangat rendah (sangat lemah), dengan nilai $\mathrm{p}=0,863$ lebih besar dari $\alpha=0,05$ maka Ho diterima yang berarti tidak ada hubungan antara intensitas suara dengan tekanan darah diastolik pada pekerja.

Tidak ada hubungan yang signifikan antara intensitas suara dengan tekanan darah sistolik dan tekanan darah diastolik pekerja pada penelitian ini dipengaruhi oleh beberapa faktor risiko yang lain seperti umur, jenis kelamin, kebiasaan buruk responden, riwayat penyakit, dan riwayat keturunan. Hasil dari wawancara terhadap responden, diketahui 5 responden memiliki umur $>40$ tahun yang berpengaruh terhadap peningkatan tekanan darah. Hal tersebut dikarenakan pada umur tersebut tanpa disadari secara alamiah mengalami peningkatan tekanan darah yang disebabkan oleh penurunan kemampuan fungsi fisiolgis tubuh.

Seluruh responden dalam penelitian berjenis kelamin laki-laki yang pada umumnya memiliki tekanan darah lebih tinggi daripada perempuan, sehingga laki-laki memiliki risiko lebih besar untuk terkena penyakit hipertensi. Hal tersebut dipicu oleh perilaku laki-laki yang buruk atau tidak sehat seperti merokok, dan mengkonsumsi (kopi)/ minuman penambah stamina secara berlebihan. 9 dari 12 responden masih memiliki kebiasaan buruk yang dapat mempengaruhi tekanan darah meningkat seperti kebiasaan merokok setiap hari yang dapat menghabiskan rokok lebih dari 2 bungkus, kebiasaan mengkonsumsi (kopi)/ minuman penambah stamina setiap hari rata-rata bisa lebih dari 3 gelas.

Diketahui dari 12 responden terdapat 1 responden yang memiliki riwayat penyakit ginjal. Hal tersebut dapat berpengaruh terhadap penurunan kemampuan fungsi fisiologis tubuh sehingga menyebabkan peningkatan tekanan darah. Tidak hanya riwayat penyakit, riwayat keturunan juga berisiko terhadap terjadinya penyakit hipertensi. 1 dari 12 responden memiliki orang tua (ayah) dengan riwayat penyakit hipertensi. Hal tersebut dapat berisiko terhadap responden terkena hipertensi dikarenakan penyakit hipertensi merupakan penyakit menurun dari anggota keluarga kandung yang memiliki genetik sama.

\section{IV.SIMPULAN}

1. PT. Tradha AMP merupakan salah satu perusahaan penghasil hotmix (aspal beton) yang bergerak di bidang usaha Stone Crusher dan Asphalt Mixing Plant (AMP) di Kabupaten Kebumen Jawa Tengah. Proses kegiatan usaha sumber-sumber paparan intensitas suara berasal dari alat-alat atau mesin-mesin produksi yang digunakan oleh perusahaan dalam proses produksi seperti mesin generator, mesin Stone Crusher (pemecah batu), Whell Loader dan Asphalt Mixing Plant (mengolah hotmix) sehingga menimbulkan paparan intensitas suara terhadap pekerja.

2. Suhu dan kelembaban diperoleh rata-rata suhu tertinggi yaitu $28,67^{\circ} \mathrm{C}$ pada lokasi Asphalt Mixing Plant dan suhu terendah pada lokasi perkantoran yaitu $26,33^{\circ} \mathrm{C}$, sedangkan rata-rata kelembaban tertinggi yaitu $66,33 \%$ pada lokasi area perkantoran dan kelembaban terendah yaitu 65,67\% pada lokasi Stone Crusher.

3. Rata-rata intensitas suara tertinggi pada titik 1 lokasi mesin Stone Crusher yaitu 87,93 dB, sedangkan rata-rata intensitas suara terendah pada titik 5 lokasi antara mesin Stone Crusher dan AMP yaitu $65,43 \mathrm{~dB}$.

4. Rata-rata tekanan darah sebelum bekerja terpapar intensitas suara tekanan darah sistolik tertinggi yaitu 128,33 $\mathrm{mmHg}$ dan terendah yaitu 103,33 $\mathrm{mmHg}$, sedangkan rata-rata tekanan darah diastolik tertinggi yaitu $81,67 \mathrm{mmHg}$ dan terendah yaitu $70 \mathrm{mmHg}$. Rata-rata tekanan darah sistolik tertinggi setelah bekerja terpapar intensitas suara 87,93 dB yaitu $138,33 \mathrm{mmHg}$ dan terendah yaitu $113,33 \mathrm{mmHg}$ dengan paparan intensitas suara $80,11 \mathrm{~dB}$, sedangkan rata-rata tekanan darah diastolik tertinggi setelah bekerja terpapar intensitas suara $87,93 \mathrm{~dB}$ yaitu 90 $\mathrm{mmHg}$, dan terendah yaitu $76,67 \mathrm{mmHg}$ dengan paparan intensitas suara $85,73 \mathrm{~dB}$.

5. Hasil analisis uji statistik menunjukkan tidak ada hubungan antara intensitas suara dengan tekanan darah sistolik dan tekanan darah diastolik pada pekerja PT. Tradha AMP tahun 2015. Diperoleh nilai hitung $\mathrm{r}_{\mathrm{xy}}=0,222$ menunjukkan hubungan intensitas suara dengan tekanan darah sistolik rendah (lemah), dengan nilai $\mathrm{p}=0,488$ lebih besar dari $\alpha=0,05$, sedangkan diperoleh nilai hitung $r_{x y}=$ 0,056 menunjukkan hubungan intensitas suara dengan tekanan darah diastolik sangat rendah 
(sangat lemah), dengan nilai $\mathrm{p}=0,863$ lebih besar dari $\alpha=0,05$.

\section{UCAPAN TERIMAKASIH}

Peneliti mengucapkan terimakasih kepada Ibu Dra. Hj. Lilis Nuryani selaku pemilik PT. Tradha $A M P$ yang telah memberikan ijin kepada peneliti untuk dapat melaksanakan penelitian karya tulis ilmiah di tempat tersebut, serta kepada pekerja yang telah bersedia menjadi responden yang baik dalam penelitian ini.

\section{DAFTAR PUSTAKA}

A., Siswanto, 1990, Kebisingan, Jawa Timur: Balai Hiperkes dan KK.

Aditama Tj. Y., 2005, Mayo Clinic Hipertensi, PT. Duta Prima, Jakarta: Indonesia University Press

Tri Hastuti, 2006, Kesehatan dan Keselamatan Kerja, Jakarta: Universitas Indonesia Press.

Anis, 2005, Seri Kesehatan Umum PAK, Jakarta: Elex Media Komputindo.

Aris Santjaka, 2011, STATISTIK untuk Penelitian Kesehatan 1, Yogyakarta: Nuha Medika.

Aziz Alimul Hidayat, 2010, Metode Penelitian Kebidanan dan Teknik Analisis Data, Jakarta: Salemba Medika.

Beevers, D.G., 2002, Seri Kesehatan Bimbingan Dokter Anda Tekanan Darah, Jakarta: Dian Rakyat Jakarta.

Budiman Chandra, 2007, Pengantar Kesehatan Lingkungan, Jakarta: Penerbit Kedokteran EGC.

Dinar Hartanto, 2011, Hubungan Kebisingan dengan Tekanan Darah pada Karyawan Unit Compressor PT. Indo Acidatama. Tbk. Kemiri, Kebakkramat, Karanngayar, Surakarta.

Dokumen UKL-UPL PT. Tradha AMP Tahun 2007.

E., Rahajeng, Sulistiyo T., 2009, Prevalensi hipertensi dan determinannya di Indonesia, Majalah Kedokteran Indonesia, volume 59,12: 580-587.

Eny Hastuti, 2004, Pengaruh Bising Terhadap Kenaikan Tekanan Darah Pada Pekerja Di Bandara Ahmad Yani Semarang, Tesis, Universitas Diponegoro Semarang.
Gunawan, Lany., 2001, Hipertensi (Tekanan Darah Tinggi), Kanisius, Yogyakarta.

Guyton, Hall., 2008, Buku Ajar Fisiologi Kedokteran, Jakarta: EGC. p: 173

Hartati, 2011, Perbedaan Tekanan Darah Tenaga Kerja Sebelum Dan Sesudah Terpapar Kebisingan Melebihi NAB Di Unit Boiler Batubara PT. Indo Acidatama, Tbk. Kemiri, Kebakkramat, Karanganyar, Surakarta.

Haryono, Subaris H., 2007, Hygene Lingkungan Kerja, Jogjakarta: Mitra Cendekia Press.

Hermawati E., 2005, Perbedaan Tekanan Darah Tenaga Kerja Dengan Intensitas Kebisingan Yang Berbeda, Universitas Negeri Semarang.

Http:// ikma.weebly.com. Diakses tanggal 1 Juli 2015. Pukul 16.00 WIB.

K3LL, 2003, Pedoman Program Konservasi Pendengaran, Jakarta: K3LL PERTAMINA.

Keputusan Menteri Kesehatan RI No. 1405/MENKES/SK/XI/2002 tentang Persyaratan Kesehatan Lingkungan Kerja Perkantoran dan Industri, Jakarta.

Keputusan Menteri Lingkungan Hidup No. 48 Tahun 1996 tentang Baku Tingkat Kebisingan, Jakarta.

Kusmindari D., 2008. Pengaruh Intensitas Kebisingan pada Proses Sugu dan Proses Ampelas terhadap Pendengaran Tenaga Kerja di Bengkel Kayu X. Palembang : Jurnal Ilmiah TEKNO. 5: 87-96 (27 November 2014)

Miswar, 2004, Faktor-faktor Risiko Terjadinya Hipertensi Esensial di Kabupaten Klaten (Tesis).

Moeljosoedarmo S., 2008, Hygiene Industri, Jakarta : Fakultas Kedokteran Universitas Indonesia, p : 340.

Pearce E. C., 2009, Anatomi dan Fisiologi untuk Paramedis, Jakarta : PT. Gramedia Pustaka Utama p : $169-171$.

Peraturan Menteri Tenaga Kerja dan Transmigrasi No. PER.13/MEN/X/2011 tentang Nilai Ambang Batas Faktor Fisika dan Faktor Kimia di Tempat Kerja, Jakarta

Sani A., 2008, Clinical Practice Pocket Book Cardiovascular Disease, Series Jurnal Kesehatan Masyarakat 2:9 (27 November 2014) 
Sasongko, Dwi, dkk., 2000, Kebisingan Lingkungan, Semarang : Badan Penerbit Universitas Diponegoro Semarang.

SK Dirjen P2M dan Penyehatan Lingkungan Pemukiman Departemen Kesehatan RI Nomor 70-1/PD.03.04.Lp. (Petunjuk Pelaksanaan Pengawasan Kebisingan yang Berhubungan dengan Kesehatan tahun 1992, 1994/1995).

Soeripto M., 2008, Hygiene Industri, Jakarta : Penerbit buku FKUI.

Subagiya E., 2007, Perbedaan Tekanan Darah Sebelum dan Sesudah Terpapar Panas pada Pekerja Bagian Moulding Perum Perhutani Unit I Jawa Tengah, Skripsi : Semarang.

Suma'mur PK., 2009, Hygiene Perusahaan dan Kesehatan Kerja, PT. Gunung Agung : Jakarta.

Sugiyono, 2002, Statistika untuk Penelitian, Bandung VC Alfabeta.

Tahang A.S., 2004, Profil Tekanan Darah P.G. Krebet Malang terhadap Kebisingan di Tempat Kerja dan Beberapa Faktor yang Diduga Berperan, Jurnal Sains dan Teknologi, 2-1-3 (26 Oktober 2014)

Tambunan S., 2005, Kebisingan di Tempat Kerja, Yogyakarta : Andi.
Tarwaka, dkk., 2004, Ergonomi untuk Keselamatan, Kesehatan Kerja dan Produktivitas, Surakarta : UNIBA PRESS.

Undang-undang Republik Indonesia Nomor 1 Tahun 1970 tentang Keselamatan Kerja, Jakarta : Presiden.

Undang-undang Republik Indonesia Nomor 3 Tahun 1992 tentang Jaminan Sosial Tenaga Kerja, Jakarta : Presiden.

Undang-undang Republik Indonesia Nomor 5 Tahun 1994 tentang Perindustrian, Jakarta : Presiden.

Undari, Janti., 2006, Prevalensi Hipertensi Terkait dengan Stress Kerja dan Faktor-faktor Lain yang Berhubungan pada Karyawan Rumah Sakit X di Jakarta, Thesis Program Studi Kedokteran Kerja, Program Pasca Sarjana, Fakultas Kedokteran, Universitas Indonesia : Depok.

Vina Anggraeni, 2012, Tingkat Kebisingan Lalu Lintas dan Risiko Hipertensi pada Supir Angkutan Umum KWK Wilayh Jakarta Timur, Depok : Skripsi Universitas Indonesia.

Vitahealth, 2000, Hipertensi, PT. Gramedia Pustaka Utama : Jakarta.

WHO, 2001, Pengendalian Hipertensi, ITB, Organisasi Kesehatan Sedunia : Bandung. 